\title{
Economics of drought-tolerant pastures for cattle finishing on Hawkes Bay and Wairarapa hill country farms
}

\author{
C.J. KORTE' and A.P. RHODES ${ }^{2}$ \\ ${ }^{\prime}$ AgResearch, PO Box 8144, Havelock N orth \\ ${ }^{2}$ Agriculture New Zealand, Dannevirke
}

\begin{abstract}
Planting drought-tolerant pastures (tall fescue, chicory, prairie grass) is one option Hawkes Bay/ Wairarapa farmers can use to reduce the impact of drought. To evaluate this strategy two hill country sheep/beef farm models were established and entered in HerdEcon, a bioeconomics computer model. Using the two farm models, three comparisons were made: (1) base farm (no alternative pasture), (2) alternative pasture planted on $5 \%$ or $10 \%$ of grazable area, and (3) same as 2 , with changes in cattle selling policy. Models were run for a 19-year sequence based on pasture growth for Hawkes Bay, and with a range of beef prices and pasture renewal costs. Drought-tolerant pastures increased the financial returns from both farm models, provided that livestock policies allowed increases in pasture quality and summer pasture growth to be captured by increased beef production. Lower pasture establishment costs and improved persistence would significantly improve profitability from drought-tolerant pastures.
\end{abstract}

Keywords cattle, dryland pastures, economics

\section{Introduction}

Climatic variability, especially drought, has a major impact on the viability of east coast sheep/beef farming systems. For example, the 1988-89 drought which affected the east coast of the North Island was estimated to have reduced regional farm income by $\$ 240$ million, and total regional income by $\$ 1000$ million (Nield 1990). Computer simulation models can be used to identify farming strategies which reduce the impact of climatic variability. Planting drought-tolerant pastures (tall fescue, cocksfoot, phalaris, chicory) is one strategy which has been promoted and adopted by east coast farmers since the 1988-89 drought to reduce the impact of climatic variability. The objective of the research presented in this paper was to evaluate the economic impact of planting drought-tolerant pastures for Hawkes Bay and Wairarapa hill country farms, and to identify variables that were associated with a positive and sustainable financial outcome. Full details of the work are given in an unpublished report (Korte \& Rhodes 1992).

\section{Methods}

The computer programme $R A N G E P A C K$ HerdEcon was used for this research because it is designed to evaluate the impact of climate and market variability (Stafford Smith \& Foran 1988 1990). The programme is able to integrate aspects of biological and economic management of a farming enterprise, including variable livestock performance levels and produce prices for years with different climate conditions. Accumulated cash flows can be used to evaluate the risks and profitability of different management strategies. Most assumptions used in this study are based on the authors' knowledge; scientific information for the specific situations modelled is extremely limited.

Pasture production records from Hawkes Bay were used as the basis for developing a 19-year sequence of year types for 1972-1992 (Korte \& Rhodes 1992). The classification of each year was based on deviations from the average monthly pasture production for the period December-April. The frequency of different year types was: Good $30 \%$, Okay (average) $40 \%$. Poor $20 \%$. and Bad (severe drought) $10 \%$. Relative levels of herbage production for December-April in different year types was: Good $\mathbf{1 5 5 \%}$, Okay $100 \%$. Poor $\mathbf{7 8 \%}$, Bad 13\%. The 1972-1992 sequence was used in model runs presented in this paper, with Bad years in 1982/83 and 1988/89.

Two east coast farm models were established and entered into HerdEcon: a Hawkes Bay-Wairarapa $\mathbf{H}$ ard Hill model and a Hawkes Bay Easy Hill model (Table 1). These models were based on Ministry of Agriculture and Fisheries farm monitoring models (MAF 1991). Both models had a breeding ewe flock producing wool and sheep for sale. The Hard Hill model had a breeding beef cow herd and sold finished 30-month-old steers. The Easy Hill model had a Friesian bull beef finishing system, with weaners being purchased and bulls being sold at either 18 months or 30 months. Produce prices and farm costs were based on 1991/92 prices. Steer and bull beef prices were $\$ 1.40 / \mathbf{k g}$ liveweight in average years (Okay). 
Table 1 Base farm model grazing area, livestock, and annual cash flows for an average year.

\begin{tabular}{|c|c|c|}
\hline & Hard Hill & Easy Hill \\
\hline $\begin{array}{l}\text { Source data } \\
\text { MAF farm class' } \\
\text { Hill farm model }\end{array}$ & $\begin{array}{c}3 \\
\text { Hawkes Bay/ } \\
\text { Wairarapa }\end{array}$ & $\begin{array}{r}4 \\
\text { Hawkes } \quad \text { Bay }\end{array}$ \\
\hline $\begin{array}{l}\text { Farm area (ha) } \\
\text { Grazing area }\end{array}$ & 600 & 315 \\
\hline $\begin{array}{l}\text { Livestock wintered } \\
\text { Breeding ewes } \\
\text { Total sheep } \\
\text { Breeding cows } \\
\text { Steers }^{2} \\
\text { Friesian bulls } \\
\text { Total cattle }\end{array}$ & $\begin{array}{c}2709 \\
3644 \\
113 \\
90 \\
282\end{array}$ & $\begin{array}{l}16.59 \\
2074\end{array}$ \\
\hline $\begin{array}{l}\text { Stock units } \\
\text { Total } \\
\text { Sheep:cattle } \\
\text { SU/ha }\end{array}$ & $\begin{array}{c}4808 \\
70: 30 \\
8\end{array}$ & $\begin{array}{c}3444 \\
75: 25 \\
11\end{array}$ \\
\hline $\begin{array}{l}\text { Annual Revenue (\$) } \\
\text { Sheep } \\
\text { Wool } \\
\text { Cattle } \\
\text { Total }\end{array}$ & $\begin{array}{r}44,000 \\
55,600 \\
46.300 \\
145,900\end{array}$ & $\begin{array}{c}32.300 \\
46,800 \\
57,700 \\
136,800\end{array}$ \\
\hline $\begin{array}{l}\text { Annual Expenditure (\$) } \\
\text { Farm working expenses } \\
\text { Debt servicing } \\
\text { Owners drawings } \\
\text { Total }\end{array}$ & $\begin{array}{c}61,600 \\
29,100 \\
30,000 \\
140,700\end{array}$ & $\begin{array}{c}69,200 \\
33.700 \\
30,000 \\
132,900\end{array}$ \\
\hline Annual Cash surplus $(\mathbf{\$})$ & 5.200 & 3,900 \\
\hline
\end{tabular}

To enable the impact of drought-tolerant alternative pastures to be evaluated, farm operating costs, and cattle growth rates were increased. Key assumptions included:

* $5 \%$ of the Hard Hill mode1 farm and $10 \%$ of the Easy Hill model farm sown in drought-tolerant alternative pasture (tall fescue/white clover/red clover, chicory, prairie grass/white clover/red clover). This represented half of the estimated cultivatable area (Korte et al. 1991; Morton et al. 1992) on each farm. The pasture mixtures were selected to provide high quality forage for finishing cattle, and to extend the period of pasture growth during dry summers.

* The annual cost associated with the area of droughttolerant alternative pastures was $\$ 263 / \mathbf{h a}$ for the Hard Hill model and $\$ \mathbf{1 9 0 / h a}$ for the Easy hill model. This cost included interest on additional capital, annual renewal of $20 \%$ of the alternative pasture area, and additional fertiliser. The costs of pasture renewal used were $\$ 600 /$ ha for Hard Hill and $\$ 480 /$ ha for Easy Hill.
Drought-tolerant alternative pastures were used for growing beef animals with high gross margins: steers in the Hard Hill model and bulls in the Easy Hill model. Benefits were reflected in higher growth rates, increases depending on cattle age, year type and month of the year (Korte \& Rhodes 1992).

Figure 1 gives an example of how growth rates were increased for bulls in average years (17\% increase over 20 months). The corresponding increases for Good, Poor and Bad years were respectively $17 \%, 9 \%$ and $6 \%$.

Figure 1 Assumed bull liveweight gain (kg/day) for bulls from purchase of weaners in November to sale at 18 months (average year).

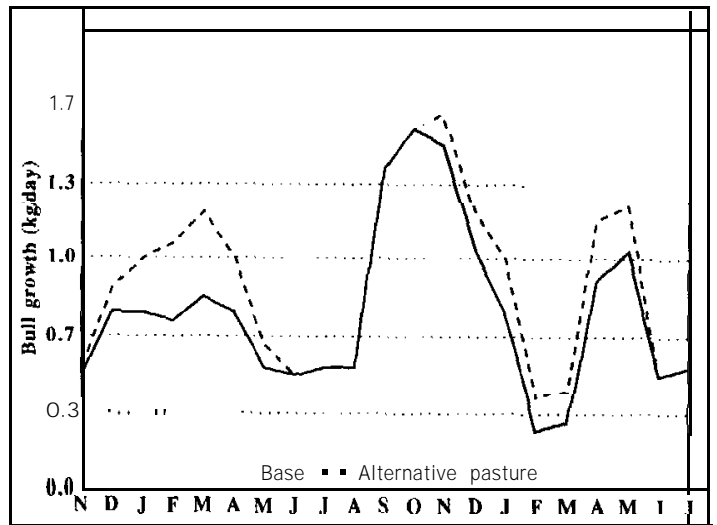

* Alternative pasture species were evaluated both with and without a change in cattle selling policy. Model runs are referred to as base model, alternative pasture model (mode1 with drought-tolerant alternative pastures and the same livestock selling policies as the base model) and the changed cattle policy model (model where an increased number of steers or bulls were sold at 18 months rather than at 30 months of age). The changed policy was an attempt to optimise returns from alternative pasture.

* Sensitivity analysis examined the impact of the establishment cost of alternative pastures (200-800 $\$ / \mathrm{ha}$ ) and of beef prices (0.80 to $2.00 \$ / \mathbf{k g}$ liveweight). In the Easy Hill model, weaner bull purchase price was linked to beef prices.

The overall financial performance of farms was evaluated from the accumulated cash surplus, i.e., the annual cash surplus (Table 1) accumulated over a model run of 19 years. The accumulated cash surplus is equivalent to the farm current account balance, including interest costs and receipts. The accumulated surplus was set to zero at the start of each model run. 


\section{Results}

Drought reduced winter livestock numbers by $7 \%$ and recovery took 1-3 years to reach pre-drought levels (Korte \& Rhodes 1992). The impact of drought on stock numbers and revenue was more prolonged for livestock policies based on breeding replacements (ewes, cows) than for those policies based on livestock trading (bulls).

Drought increased debt levels by $24 \%$ for the Hard Hill model farm and by $17 \%$ for the Easy Hill model farm (Korte \& Rhodes 1992). These increases were considerably higher than the actual $4 \%$ increase reported after the 1988/89 drought (Bailey et al. 1992), the difference being explained by farmers reducing expenditure on maintenance items after drought, while such expenditure was maintained in the model farms.

For model runs with the 19-year sequence (Figure 2), accumulated cash surplus results reflected the effect of summer pasture growth variability on livestock production and prices. Both base models were profitable, having a positive accumulated surplus at the end of the sequence, despite there being droughts in years 9 and 15. The effect of alternative pastures and changes in cattle selling policy differed for the Hard Hill and Easy Hill model farms.

For the Hard Hill model (Figure 2), the run with alternative pastures was more profitable than the base model. The changed steer selling policy with alternative pastures was less profitable than the base model. Alternative pastures increased accumulated cash surplus compared with the base model due to cattle being sold at heavier weights in most years. With $30 \%$ of steers sold at 18 months instead of 30 months, made possible by higher quality alternative pasture, accumulated cash surplus was reduced. With the changed policy, average steer sale weight was reduced (590 compared with 630 $\mathrm{kg}$ LW) although steer growth rates were improved. Despite reduced profitability with the changed cattle policy, flexibility was increased due to a proportion of steers being ready for sale a year earlier

For the Easy Hill model (Figure 2), additional revenue generated with alternative pastures was less than alternative pasture maintenance costs, so that accumulated cash surplus was reduced compared with the base model, With a change in bull selling policy, accumulated cash surplus was increased compared with the base model. The change in bull selling policy resulted in more bulls being sold each year than in the Base model (136 compared with 115), at a similar weight to bulls in the Base model (575 kg LW).

There was no evidence that drought-tolerant alternative pastures reduced variability in either farm income or profitability (Korte \& Rhodes 1992). Climate
Figure 2 Accumulated cash surplus for models run with the 19 year sequence.

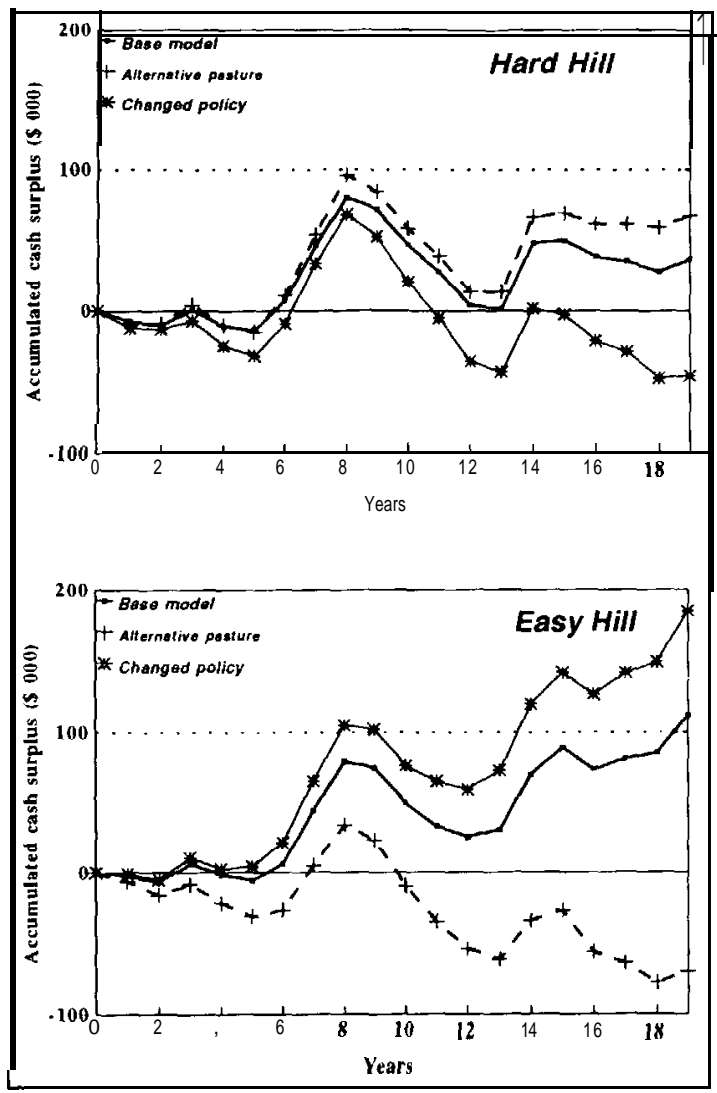

remained the predominant source of variability in farm income and profitability in all models, even when revenue was increased with alternative pastures. For example, in the Hard Hill model, mean and standard deviation for annual total farm revenue during the 197292 sequence was: base model \$140 $200 \pm \$ 20900$; alternative pasture model $\$ 149000 \pm \$ 23200$.

Sensitivity of accumulated cash surpluses (or deficits) at the end of model runs for a range of beef and pasture renewal prices are presented for the base model and for the most profitable alternative pasture option in Table 2. Over the range evaluated, both beef price and pasture renewal cost affected accumulated surplus, changes in beef price tending to have a greater impact than changes in cost of pasture renewal. Results were used to calculate a break-even point for different pasture renewal costs (Figure 3) - the minimum beef price at which the alternative pasture model had the same financial result as the Base model. For any pasture establishment cost, the break-even beef price was similar for both models. Pasture establishment costs are 
typically higher for Hard Hill than Easy Hill, and the break-even beef prices were $\$ 1.30 / \mathrm{kg} L W$ and $\$ 1.12 / \mathrm{kg}$ LW respectively.

\section{Discussion}

\section{Assumptions}

A discussion of assumptions in the base models is given in Korte \& Rhodes (1992). The base models mirrored actual farms with respect to key aspects of physical production and revenue associated with climate variability: drought reduced livestock numbers and revenue, both models and farms taking several years to recover; livestock policies based on trading were less sensitive to drought than those based on breeding; and equity level affected the financial impact of climatic variability. Because maintenance costs were treated as fixed rather than variable, the impact of adverse climatic events had a more immediate effect on cash flow in the models than typically seen on farms.

For this study, an attempt was made to establish an overview of the potential economic impact of droughttolerant alternative pasture, highlighting the main constraints to adoption of the technology. The analysis and assumptions were not intended to address detailed questions relating to specific pasture species or management practices. The transition into a new technology like drought-tolerant pasture species can be associated with several years' delay between timing of investment and response. As a preliminary assessment, the status quo following pasture establishment was considered, and the transition was ignored.

Modelled benefits of alternative pastures were largest in Good years and least in Bud (drought) years. This pattern of benefits for Bud years was based on the assumption that during severe drought insufficient moisture is available for any pasture type to produce significant forage, drought-tolerant alternative pastures extending feed availability later into the dry period and providing more rapid recovery after drought. During Good years forage availability is not a problem, benefits of alternative pastures coming from improved forage quality.

For this analysis it was assumed that drought-tolerant alternative pasture would be used for finishing beef cattle on the basis that this was the most profitable choice available to farmers. The financial benefit would have been reduced if areas of alternative pasture were grazed by other classes of stock. Little scientific data is presently available showing the impact of alternative pasture species on beef cattle growth rates under the range of Hawkes Bay/Wairarapa farming conditions. Farmers have, however, demonstrated that alternative pasture species do improve beef cattle growth rates compared with their traditional pastures.
Table 2 Sensitivity analysis for accumulated cash surplus (\$000) with different beef prices (\$ $\$ \mathrm{~kg}$ liveweight) and pasture renewal costs (\$/ha).

\begin{tabular}{llcccccc}
\hline Model & & \begin{tabular}{c} 
Renewal \\
cost \\
\cline { 4 - 8 }
\end{tabular} & & \multicolumn{4}{c}{ Beef price $\left(\$ / \mathrm{kg} \mathrm{LW}^{1}\right.$} \\
\cline { 4 - 8 } Hha & 1.00 & 1.20 & 1.40 & 1.60 & 1.80 \\
\hline Hard Hill: & Base & None & -495 & -192 & 37 & 184 & 327 \\
Hard Hill: & Alternative & 200 & -335 & 8 & 204 & 389 & 575 \\
& pasture & 500 & -557 & -165 & 100 & 298 & 474 \\
& & 800 & -784 & -373 & -19 & 186 & 373 \\
Easy Hill: & Base & None & -981 & -347 & 112 & 391 & 671 \\
Easy Hill: & Changed & 200 & -847 & -127 & 282 & 609 & 936 \\
& policy & 500 & -1078 & -344 & 178 & 508 & 835 \\
& & 800 & -1308 & -573 & 69 & 405 & 733 \\
\hline
\end{tabular}

Beef prices on a liveweight basis are approximately half carcase weight prices, depending on weight and age at slaughter.

Figure 3 Minimum beef prices for the costs of alternative pastures to be recovered by increased beef returns. The pasture establishment costs in the base models are also indicated.

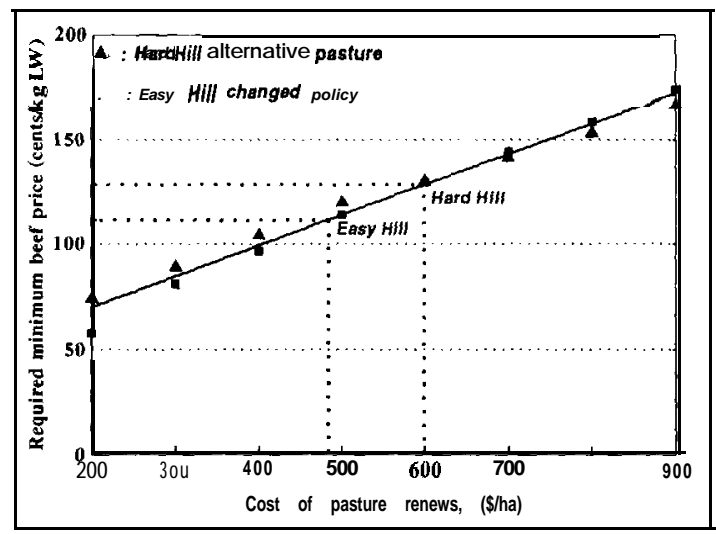

\section{Capturing benefits of alternative pasture}

Numerous experiments have highlighted the need to design animal production systems capable of capturing the benefits of changes in forage supply. For example, White (1987) discussed how extra herbage has to be consumed by animals if an economic benefit is to be obtained from fertiliser. With drought-tolerant alternative pastures, the bull beef system modelled resulted in heavier cattle, but the most significant economic benefit was obtained when the number of bulls sold was able to be increased (Alternative pasture plus changed cattle policy). The change in bull selling policy would not have been profitable without access to alternative pastures. For the Hard Hill farm model, increasing steer weights without a change in selling policy was the better method of utilising alternative pastures. The important point illustrated was that farmers need to identify how they will optimise their livestock 
policies to capture the benefits of drought-tolerant pasture, rather than expect benefits to automatically appear.

The sensitivity analysis illustrated how the cost of pasture establishment has a marked impact on profitability of farms with alternative pastures. Lower pasture establishment costs improve profitability. Where farmers are involved in cropping or already have suitable machinery, the marginal costs of alternative pastures could be substantially lower than the levels modelled (\$600/ha for Hard Hill and $\$ 480 /$ ha for Easy Hill). Recently conducted modelling studies (unpublished) for farms where pasture renewal is a feature of the farm system and the marginal cost of changing to alternative pastures is low (less than $\$ 100 / \mathrm{ha}$ ), have shown considerably greater financial benefit of alternative pastures than apparent for the hill country farms modelled in this study. The relatively high cost of pasture establishment presumably explains why pasture renewal on the east coast has largely been restricted to farms involved in cropping (Korte et al. 1991).

\section{Conclusions}

In evaluating the use of alternative pastures, the main conclusions were:

* A clear strategy for capturing the changed patterns of herbage production and quality is required to obtain financial benefits from drought-tolerant alternative pastures. Changes in livestock policy may be required.

* Costs of establishing drought-tolerant alternative pastures are relatively high for the farm types modelled and affected the profitability of such pastures. Lower establishment costs and improved persistence would significantly improve profitability.

* Using drought-tolerant alternative pastures did not reduce year-to-year variability in farm profitability caused by climate, even when revenue and accumulated cash surplus were increased.

\section{ACKNOWLEDGEMENTS}

Brent Pownell is acknowledged for his assistance with this project in 1991/92, Barney Foran for his assistance in training Tony Rhodes in the use of HerdEcon, and colleagues in AgResearch for comment on the manuscript. The project was funded jointly by the
Foundation of Research Science and Technology and the New Zealand Meat Research and Development Council.

\section{REFERENCES}

Bailey, A.; Ussher, R.J.; Kummer G.H. 1992. An analysis of the economic position of East Coast, North Island sheep \& beef cattle farmers. Report from New Zealand Rural Support Trust as part of the Ministry of Agriculture and Fisheries East Coast Drought Recovery Programme.

Korte, C.J.;, Rhodes, A.P. 1992. Computer modelling of drought tolerant farm systems. Unpublished report for the New Zealand Meat Producers Board Meat Research and Development Council project $91 \mathrm{MT}$ 3013.1.

Korte, C.J.; Smith, D.; Slay, M.W.A.; Gray, M.; Quilter, S.J. 1991. Preliminary report on a survey of performance of drought tolerant pastures on East Coast sheep/beef farms. MAF Technology, Hastings.

MAF 1991. MAF farm monitoring report, North Central Region, June 1991. MAF Policy Rural Affairs and Policy Unit, Ministry of Agriculture and Fisheries, Palmerston North.

Morton, J.D.; Korte, C.J.; Smith, D. 1992. Preliminary report on a survey of nitrogen fertilizer practices on East Coast sheep/beef farms. MAF Technology, Canterbury Agriculture \& Science Centre, Lincoln.

Nield, J.D. 1990. Regional economic impacts of the 1988189 drought on the East Coast of the North Island. Report prepared for the Regional Policy Manager, MAF Technology, North Central Region, Batchalar Agriculture Centre, Palmerston North, January 1990.

Stafford Smith, D.M.; Foran, B.D. 1988. Strategic decisions in pastoral management. Australian rangelands journal 10:82-95.

Stafford Smith, D.M.; Foran B.D. 1990. RANGEPACK: the philosophy underlying the development of a microcomputer based decision support system for pastoral land management. Journal of biogeography 17: $541-546$.

White, D.H. 1987. Chapter 24: Stocking rate. In Managed grasslands (Ecosystems of the world 17A), Snaydon, R.W. ed. Elsevier Science Publishers, Amsterdam. 